\title{
Analysis of differences in measurement of fair value and historical value of biological assets on income smoothing (Study on agricultural companies in Southeast Asia and Australia)
}

\author{
Nopfiana Lestari, Satia Nur Maharani* \\ Universitas Negeri Malang, Jl. Semarang No. 5 Malang, Jawa Timur, Indonesia \\ *Corresponding author, Surel: satia.nur.fe@um.ac.id
}

Paper received: 1-4-2021; revised: 22-4-2021; accepted: 29-4-2021

\begin{abstract}
Biological assets are assets of living things in the form of animals and plants. There have been various debates regarding the measurement of biological assets. The debate is related to the use of fair value and historical value in measuring biological assets. Historical value is considered less relevant because it does not reflect present value, while fair value is not considered as expected because it causes fluctuations in earnings and retains manipulation. This study aims to analyze the effect of fair value and historical value measurements on biological assets on income smoothing and the tendency of earnings manipulation in companies that use fair value. The results of different tests show that there is not enough evidence to state that companies that use fair value tend to have higher income smoothing than companies that use historical value. Based on the results of this study, it is suggested that investors should not only focus on company profits but also use other considerations such as future economic conditions, management performance, and government regulations.
\end{abstract}

Keywords: biological assets; fair value; historical value; income smoothing

\section{Introduction}

Selection of the right accounting method is necessary to ensure that each element in the financial statements has been treated according to applicable rules in order to avoid biased information. In several business fields that have special characteristics, for example agribusiness companies that have biological assets, require different accounting treatment fromother business fields.

IAS 41 describes biological assets as assets of living things in the form of animals and plants, which have unique characteristics because they continue to change from time to time. Biological transformation consists of processes of growth, degeneration, production and procreation that cause qualitative and quantitative changes in the life of these animals and plants. These assets can also generate new assets in the form of derivatives of similar biological assets. Because the biological assets continue to experience changes in product capacity, measurements are needed that can show the value of these assets fairly in accordance with their role in generating economic benefits for the company.

There are two methods of valuing biological assets, namely using historical value and using fair value. Based on historical value, biological assets are recorded at cost plus costs incurred during the maintenance of the biological assets. Meanwhile, the measurement of biological assets based on fair value is in accordance with the International Accounting Standards (IAS) 41 issued by the IASC, biological assets are measured at fair value less costs to sell. Fair value is determined using official market prices in active markets (level 1 input). If 
there is no official market price, fair value is determined using the value of similar assets (level 2 input). If the value of similar assets cannot be obtained, then fair value is generated through an appraisal by an independent appraiser (level 3 input). Different methods of measuring biological assets result in different biological asset values which will also affect the overall asset value.

In Indonesia, PSAK has not specifically regulated the treatment of biological assets, so there is no standard regulating how information on biological assets can be used as reliable and relevant information in decision making. As an agricultural country, the agricultural sector has a strategic role in national development in Indonesia. Plantation is part of agriculture, through the oil palm plantations as one of the main commodities that have become a source of non-oil and gas foreign exchange earnings for Indonesia, absorbing plantation labor and a source of income for farmers.

Indonesia's potential in the agricultural sector will encourage investors to invest in this sector. Selection of the appropriate accounting method will produce relevant and reliable financial reports that will assist investors in making investment decisions. Based ondata Oilworld, the total production of 17 types of vegetable oils and fats in the world will reach 236 million tons in 2020 with palm oil and soybean oil as the main production. The high demand for palm oil is an opportunity for Indonesia to fill the demand, considering that Indonesia is the world's largest producer of palm oil (Amri, 2010).

In the international world, there have been various debates regarding the measurement of biological assets. The debate relates to the use of fair value and historical value in measuring biological assets. Biological assets are initially measured using historical values. Along with the development of science, historical value is seen as less relevant because it does not reflect current values. Sonbay (2010: 2) explains that the historical value method in accounting records contained in the financial statements does not reflect the true value. This is due to changes in the value of the currency from time to time. Many historical figures that appear in financial statements are not economically relevant because prices continue to change. Historical value can be used if economic conditions are normal (no inflation).

Barlev (2003: 384) states that historical value-based financial reports obscure the real financial statements and results of company operations and provide a lot of room for manipulation. Often the book values of assets and liabilities have values that are significantly different from market values. This situation allows management to manipulate reported earnings to hide their poor performance.

Fair value emerged as a response to dissatisfaction with historical value. However, the fair value is deemed not in line with expectations. Watts (2003: 3) argues that fair value is the subject of manipulation and adjustment, therefore fair value is a weak measurement tool in valuation and performance compared to the use of fair value. Rayman (2007: 211) concluded that fair value accounting is responsible for misleading information. Ronen (2008: 200) reinforces the criticism of fair value by explaining that fair value accounting is less reliable and is the subject of manipulation.

Penttinen et al. (2004: 67) states that measurement using fair value will not be achieved if the value cannot be measured reliably. This study also claims that measurement using fair value causes unrealistic fluctuations in profit in forestry companies. Meanwhile, Argiles (2009: 
1) in his study denied this by stating that there is no difference in the relevance of cash flow information between fair value and historical value. Argiles (2009) revealed that there is no significant difference between income and profitability volatility using fair value and historical value.

In Indonesia, Aryanto (2011: 3) in his study states that the use of fair value in assessing biological assets can cause a difference between book value and fair value which affects the recognition of unrealized gains and losses, thereby increasing the volatility of unrealized financial performance. In the case of biological assets certain, profits increase sharply at the beginning and fall sharply in subsequent periods.Actually, unrealized gains and losses are only a matter of time. But the problem is, the IASBdoes not take into account that there are biological assets that have very long realization times.Meanwhile, Subramanyam and Wild (2010: 125) state that fair value is vulnerable to manipulation. This relates to the methods used in measuring biological assets. The use of management assumptions causes the valuation of biological assets that uses fair value to have low objectivity, making it vulnerable to manipulation and practices income smoothing.

Fluctuating profit will increase the company's risk. In accordance with positive accounting theory, managers with the authority they have will choose an accounting method that can regulate the size of profits and take actions income smoothing. Income smoothing is defined as the practice of determining the timing of the recognition of income and expenses carefully to flatten the amount of reported profit from one period to the next (Hery, 2009: 45). This action is carried out by the manager with the aim of creating a stable profit, so that it can influence investors to assess the company's performance. If the assessment of the company is good, it is expected that stock prices and stock returns will increase. This condition will help managers in maintaining their positions. Income smoothing, which is part of earnings management, often creates a bad perception from the public. This action has generated a lot of controversy. On the one hand, earnings management is an action that does not violate existing and generally accepted regulations. However, on the other hand, Stolowy and Breton (2000: 4) argue that earnings management is a form of accounting manipulation.

practice Income smoothing reduces the reliability of financial statements. This isbecause income smoothing tends to measure profits or report profits that do not reflect the actual conditions. This action occurs because there is an opportunity provided by accounting standards so as to encourage the possibility of manipulation.

Kaur (2013: 8) states that fair value supporters argue that income smoothing and earnings management are possible if using historical value. If the company's performance deteriorates, the company can influence the income statement through the sale of assets, profit is reported if the net selling price of the assets is greater than the book value based on historical value. Meanwhile, by using fair value assets are already valued at fair value so that profits are reflected in the income statement and reduce the possibility ofincome smoothing.

Maruli and Mita (2010: 20) state that there is no significant difference in the value and volatility of assets, income, earnings, ROA and income smoothing index between companies that use the fair value approach using the historical value approach. The study also stated that there was no different effect between the use of the fair value approach and those using the historical value approach on the volatility of earnings company. Meanwhile, this research is different from the research conducted by Tudor (2010: 76) which states that there is an increasein 
income smoothing practices in England, France and the Netherlands after the use of fair valuein accordance with IFRS

Based on the description above, the authors are interested in conducting research on the effect of using value. fair and historical value of biological assets against practices income smoothing. The samples taken are agricultural companies in Southeast Asia and Australia. Southeast Asia was chosen because it is one of the most productive agricultural areas in the world. In 2012, this region produced 129 million tons of rice, 40 million tons of corn, 171 million tons of sugar cane, 1.44 million tons of soybeans, and 70 million tons of cassava ( Invest in ASEAN, 2013). In addition, Southeast Asia is also the world's largest producer of palm oil (Amri, 2010). However, most agricultural companies in Southeast Asia still use historical values so that Australia was chosen as the comparison.

Sukendar (2012: 95) states that Australia is one of the first countries to introduce the concept of fair value which is used to calculate biological assets in the environment of plantation and livestock companies. In addition, Australia is the largest producer of wool and meat and is the largest organic agricultural country in the world (Lara, 2015). Therefore, it is necessary to conduct further research titledof "Analysis Difference Measurements Fair Value and Value of Historical on Assets Biological Against Income Smoothing (Study on Companies Agriculture in Southeast Asia and Australia)

The decision can be interpreted as an option, the choice of one or more possible. Setiadi (2008:17) explains that decision making is the process of selecting the best alternative from several alternatives systematically to be followed up (used) as a way of solving problems. Salusu (2000:47) states that decision making is the process of choosing an alternative way of acting with anefficient method according to the situation. Meanwhile, Prawirosentono (2002: 5) defines decision-making theory as how to provide guidance or guidance to people or organizations in making decisions, as well as improve the decision-making process in uncertain conditions.

Positive accounting theory explains why companies choose accounting policies as part of the deep problem of minimizing contract costs and to achieving efficiency corporate governance. Belkaoui (2007: 188) explains that positive accounting theory is based on the argument that managers, shareholders and regulatory officials / politicians are rational. Managers try to maximize the usefulness that is directly related to compensation and welfare. Watts and Zimmerman (1986) in Rahmawati (2012: 75) explain that there are three hypothesesthat are applied to make predictions in positive accounting theory regarding management's motivation to manage earnings. The three hypotheses described are as follows, first, the hypothesis bonus plan: if the company plans a bonus based on net income, then the companywill choose an accounting procedure that shifts earnings future to the present period. Second, the debt covenant hypothesis: firms tend to lower their debt / equity ratio by increasing their current profit by shifting from tomorrow's profit. The motivation of the company to do this is to avoid being close to debt covenants and to get a lower loan interest rate, because the lower the debt / equity ratio the lower the risk of company bankruptcy. Third, the political cost hypothesis: firms tend to reduce current earnings by shifting to the profit of tomorrow's period.The motivation of companies to do this is for example to avoid political pressure such as accusations of monopoly by showing that company profits are not excessive as suspected, lobbying to the congress to protect the industry from imported goods that cause 
industrial profits to decline, avoiding demands from trade unions by showing that company profits are decreasingand so on. Companies can reduce profits by changing accounting methods or procedures.

From the explanation above, it can be concluded that management will select the optimal accounting procedure to improve its welfare. This is done based on three hypotheses, namely the bonus plan hypothesis, debt contracts and the political process.

\section{Method}

This research is a comparative descriptive study. According to Arikunto (2006: 36), comparative research is research that wants to compare the status of two or more phenomena. This study aims to examine the differences in income smoothing company using fair value and historical value. The population of this study was 130 companies consisting of agricultural companies represented by agricultural companies in Southeast Asia and Australia in the 20132014 period. The sampling technique is a technique to determine the sample that will be used in the research. The technique used in sampling is purposive sampling sampling or technique with certain considerations. After the reduction of the criteria, the final sample of this study was obtained as many as 60 companies results are

Hypothesis testing used to draw conclusions from the research results. In this study, hypothesis testing is used to determine whether there differences in income smoothing are significant between agricultural companies that use fair value and historical value. Tests were carried out using the independent sample t-test. The results of the independent sample t-test are as follows:

Table 1. Results of the Independent Sample t-Test

Independent Samples Test

\begin{tabular}{|c|c|c|c|c|c|c|c|c|c|c|}
\hline & & \multicolumn{2}{|c|}{$\begin{array}{l}\text { Levene's } \\
\text { Testfor } \\
\text { Equalityof } \\
\text { Variances } \\
\end{array}$} & \multicolumn{7}{|c|}{ t-test for Equality of Means } \\
\hline & & \multirow[b]{2}{*}{$\mathbf{F}$} & \multirow[b]{2}{*}{ Sig. } & \multirow[b]{2}{*}{$\mathbf{T}$} & \multirow[b]{2}{*}{ df } & \multirow{2}{*}{$\begin{array}{l}\text { Sig. (2- } \\
\text { tailed) }\end{array}$} & \multirow{2}{*}{$\begin{array}{l}\text { Mean } \\
\text { Difference }\end{array}$} & \multirow{2}{*}{$\begin{array}{l}\text { Std.Error } \\
\text { Difference }\end{array}$} & \multicolumn{2}{|c|}{$\begin{array}{l}95 \% \text { Confidence } \\
\text { Interval of the } \\
\text { Difference }\end{array}$} \\
\hline & & & & & & & & & Lower & Upper \\
\hline \multirow{4}{*}{ IS } & Equal & .013 & .908 & 1.622 & 58 & .110 & -1.90664 & 1.17571 & - & .44679 \\
\hline & $\begin{array}{l}\text { varian } \\
\text { ces } \\
\text { assum } \\
\text { ed }\end{array}$ & & & & & & & & 4.26007 & \\
\hline & Equal & & & $\begin{array}{l}- \\
1.622\end{array}$ & $\begin{array}{l}47.9 \\
89\end{array}$ & .111 & -1.90664 & 1.17571 & - & .45729 \\
\hline & $\begin{array}{l}\text { varian } \\
\text { ces } \\
\text { not } \\
\text { assum } \\
\text { ed }\end{array}$ & & & & & & & & 4.27057 & \\
\hline
\end{tabular}


Based on table 1. above, it can be seen that the significance value is $0.908>0.05$, thenH0 is accepted. This means that even though there is an average difference of -1.90664, there isnot enough evidence to state that companies that use the fair value approach have a higher income smoothing index than companies that use historical values.

\section{Result and Discussion}

\subsection{The Effect of Fair Value Measurement on Biological Assets on Income Smoothing}

The results of data analysis described in the previous chapter show that measuring fair value on biological assets has no significant effect on the level of income smoothing of agricultural companies in Southeast Asia and Australia. This means that whether the company uses or does not use fair value in measuring biological assets, the company will continue or will not carry out practices income smoothing.

The results of this study are inconsistent with the theory that the use of fair value in measuring biological assets affects practices income smoothing. This is indicated by the average value of Agrinurture Inc.'s biological assets. which is quite low among the sample companies amounting to $\$ 3,811,091.83$, but it is included in companies that distribute profits with an income smoothing index of -3.83. Meanwhile, Indo Agri Resources Ltd. those with a fairly high average value of biological assets of $\$ 1,312,984,648.26$ are not included in the profit-leveling companies.

This research also contradicts the results of Bangun's (2014: 5) study which states that the use of fair value results in a measurement made based on the current conditions being relevant but it is difficult to determine the fair value of assets or liabilities that are not actively traded resulting in the determination of fair value through estimates or assumptions of the appraisal subjective, thus enabling great earnings management. Beattrice (2013: 96) states that when the value of agricultural products cannot be assessed reliably using fair value, this condition can reduce the quality of decisions and open up opportunities for manipulation. Feleaga (2012: 37) states that the use of fair value in the valuation of biological assets causes an increase in earnings volatility. Danbolt \& Rees (2008: 2) found that the consistent use of fair value is more relevant than historical value, they also find consistent evidence for earnings management in the form of income smoothing. Penttinen et al. (2004: 67) states that measurement using fair value will not be achieved if the value cannot be measured reliably. This study also claims that measurement using fair value causes unrealistic fluctuations in profit in forestry companies.

The factors that cause fair value measurement on biological assets do not affect practices, income smoothing among others a) the sample companies that use fair value in measuring biological assets do not use management assumptions in measuring biological assets, $b$ ) sample companies have applied Good corporate governance is seen from the elements of the audit committee, c) there is high investor protection in the country where the sample companies are. The first factor that causes fair value measurement to have no effect on income smoothing is that the sample companies that use fair value in the measurement of biological assets do not much use management assumptions. As previously explained, input level three is an unobservable input that reflects management's own assumptions regarding the assumptionsmade by market players so that it is considered a gap that encourages 
managers to undertake practices income smoothing. Of the 30 sample companies that used fair value in measuring their biological assets, only 4 companies used management assumptions, namelyFirst Resources Limited, Goodhope Asia Holding Limited, Kencana Agri Limited and SterlingPlantation Limited. The remainder use level one inputs or the official active market price invaluing biological assets. The use of market prices provides the most reliable evidence in fairvalue valuation because they are measured at prices available in an active market without adjustments and managerial assumptions that prevent manipulation.

The second factor is that the sample companies have implemented good corporate governance seen from the elements of the audit committee. Good corporate governance is a set of rules governing the relationship between shareholders, company management, creditors, employees and other internal and external stakeholders relating to their rights and obligations or in other words a system that regulates and controlling the company. Sutedi (2011:2) states that there are four main components needed in the GCG concept, namely fairness, transparency, accountability, and responsibility. These four components are important because the consistent application of GCG principles has been shown to improve the quality of financial reports and become an obstacle to performance manipulation which results in financial reports not reflecting the company's fundamental value. The GCG system provides effective protection to shareholders and creditors so that they can be sure that they will get their investment back fairly and with high value.

The sample companies already have audit committees with more than 3 members and the members of the independent audit committee. The audit committee is one of the committees formed by the Board of Commissioners and is responsible to the Board of Commissioners with the main duties and responsibilities to ensure the principles of GCG in a company, where independence, transparency, accountability and responsibility, and fairness are the principles and foundation of the organization. company. Gradiyanto (2012: 32) states that to build an effective audit committee, the range of members needed is 3-5 people, because the larger the size of the audit committee will increase the function supervisory of the audit committee on management. Yang and Khrisnan (2005) in Lin (2006) prove that there is a negative relationship between audit committee size and earnings management (discretionary accrual). These results indicate that the greater the size of the auditcommittee, the more guaranteed the quality of financial reporting. The size of the audit committee can minimize the occurrence of earnings management. This is consistent with research by Melurmutia (2014), Kusumaningtyas (2012), and Pamudji (2008) which states thatthe independence of the audit committee has a negative effect on income smoothing.

In addition to the size of the audit committee, the independence of the audit committee is also one of the reasons that the fair value measurement on biological assets does not affect income smoothing. Independence is intended to maintain integrity and an objective view in the report as well as the preparation of recommendations proposed by the audit committee, becauseindependent individuals tend to be more fair and impartial and objective in handling a problem.Independence in the audit committee will suppress manipulation, one of which is in the form ofearnings management.

The third factor that causes fair value measurement to have no effect on income smoothing is that there is high investor protection in the sample countries. The sample 
companies that use fair value in measuring biological assets are dominated by companies from Singapore and Australia. Based on the Strength of Investors Protection Index released by the World Bank, Singapore ranks the highest in terms of investor protection from 189 countries. The Strength of Investors Protection Index is assessed based on various indicators, including: (a) gender insecurity, (b) shareholder rights, (c) ownership and supervision, (d) company transparency, (e) licensing and transparency, f) shareholder actions and access to evidence. This indicates a high level of investor protection regulations. Singapore also has various investor protection agencies that have been established since 2001, namely SPIF.

The high level of investor protection will cause accountants to be more careful in preparing financial reports. This is in accordance with the research of Leuz et al. (2003) which states that strong law enforcement for the rights of investors or non-controlling shareholders will limit the incentives for management to take actions that only benefit management or controlling shareholders. Reduced incentives prevent management from undertaking earnings management because there is less to cover from investors. Kaur (2013: 8) states that by using fair value assets are already valued at fair value so that profits are reflected in the income statement and reduce the possibility of income smoothing.

Based on the description of the research findings and related theories above, it can be concluded that the use of fair value in measuring biological assets has no effect on practices income smoothing.

\subsection{Effect of Measurement of Historical Value on Biological Assets on Income Smoothing}

The results showed that measurement of historical value on biological assets has a positive and significant effect on the level of income smoothing of agricultural companies. Changes in the variable value of biological assets that are measured using historical values will cause changes in the level income smoothing company's. The results of this study are in line with theexisting theory, which is indicated by the relatively low average value of PT Provident Agro, Tbk's biological assets among the sample companies, which is $\$ 3,811,091.83$, not included inthe companies that distribute profits. Meanwhile, Indo Agri Resources Ltd. those with a fairly high average value of biological assets of $\$ 486,145,831.61$ are among the companies that areincome-leveling.

The factors that cause measurement using historical value have an effect on income smoothing are a) the falling currency exchange rate of the country where the sample companies tend to fall so that the use of historical value in measuring biological assets is considered more profitable, b) weak investor protection in the country where the sample companies are located. The first factor that causes the use of historical value to affect income smoothing is the currency exchange rate of the country where the sample companies tend to fall so that the use of historical value in measuring biological assets is considered more profitable. The sample companies that use historical values are dominated by companies from Indonesia as many as 14 companies. The Indonesian rupiah exchange rate during 2012-2014 tended to weaken against the dollar. Sonbay (2010: 6) states that using historical value, the value of assets recorded in the balance sheet will be lower when compared to the latest developments in the purchase price ofmoney. In addition, there are also rapid changes in exchange rates for assets and liabilities in foreign currencies controlled by the company so that it experiences difficulties 
in calculating the correct foreign exchange differences. This will cause companies that use historical value to report lower earnings when exchange rates tend to rise. However, the weakening of the exchange rate causes assets to be more profitable if they are valued using historical values. This occurs because assets are valuedbased on expense rather than their present value.

This research is in line with Sonbay's research (2010: 2) which explains that the historical value method in accounting records contained in the financial statements does not reflect the true value. This is due to changes in the value of the currency from time to time. In addition, Barlev (2003: 384) in his research states that historical value-based financial reports obscure the real financial statements and results of company operations and provide plenty ofroom for manipulation. Often the book values of assets and liabilities have values that aresignificantly different from their market values. This situation allows management to manipulate reported earnings to hide their poor performance.

Kaur (2013:8) states that Advocates of fair value argue that income smoothing and earningsmanagement are possible under the historical cost framework. If corporate results turn out badly, management can influence reported income under historical cost accounting through the sale of assets, as a profit is reported if thenet selling price of an asset is larger than the book value based on historical costs. But, under fair value accounting, the asset is already at fair value and theresult is reflected in the income statement, reducing the possibility of income smoothing.

The study explains that fair value proponents argue that income smoothing and earnings management are possible when using historical values. If the performance of a company deteriorates, the company can influence the income statement through the sale of assets, profit is reported if the net selling price of the assets is greater than the book value based on historical value. This factor then encourages management to do income smoothing so that reported earnings look better. This is in accordance with positive accounting theory which describes a process whereby using the appropriate skills, understanding and accounting policies, managers will maximize the existence function which is directly related to the compensation and prosperity that managers will get. The second factor that causes the use of historical values in measuring biological assets to affect income smoothing is investor protection which tends to be weak in the country where the sample companies are located. The sample companies that use historical values are dominated by companies from Indonesia. In the research year, namely 2013-2014, investor protection in Indonesia can be said to tend to be weak. Based on the Strength of Investor Protection Index, Indonesia is in position 88 out of 189.

Based on what was reported on okezone.com, several cases of manipulation of customer funds had occurred in the Indonesian capital market, such as the case of PT Sarijaya Sekuritas and PT Antaboga Delta Sekuritas which caused many investors to suffer losses. Currently, Indonesia has an investor protection agency, namely PT P3IEI. However, PT P3IEI was only established in 2013 and operated in 2014, so that in the year of research this institution has not carried out its functions optimally.

Based on the description of the research findings and related theories above, it can be concluded that the use of historical values in measuring biological assets has a positive and significant effect on the practice of income smoothing. The results of the regression test show 
that the use of historical values in measuring biological assets has an effect of $44 \%$ and the rest is influenced by other factors.

\subsection{Differences in Income Smoothing in Companies Using Fair Value and Historical Value}

The results of data analysis show that there is not enough evidence to state that companies that use fair value have a higher tendency of income smoothing index than companies that use historical values. This study is in line with research by Argiles (2001) and Maruli \& Mita (2010) which gave the same results. The results of this study are also in line with the results of the analysis of hypothesis 1 which states that there is no effect between the use of fair value in measuring biological assets on income smoothing and hypothesis 2 which states that the use of historical value in measuring biological assets has an effect on income smoothing.

The results of this study are not in line with research by Liang \& Wen (2007) which states that fair value inherits a lot of manipulation and reduces investment efficiency. And contrary to the research of Bangun (2014), Beattrice (2013), Feleaga (2012), and Danbolt \& Rees (2008) which states that fair value opens greater opportunities for profit manipulation. This insignificant research result is caused by several factors including: a) sample companies that use fair value do not use much management assumptions in measuring biological assets, while companies that use historical value in measuring biological assets are dominated by companies originating from countries experiencing exchange rate depreciation in the year of study b) companies using fair value are dominated by companies that have high investor protection.

The first factor that causes the results of the study to be insignificant is that the sample companies that use fair value do not use much management assumptions in measuring biological assets, while companies that use historical values in measuring biological assets are dominated by companies originating from countries that experienced a weakening exchange rate in the year of the study. As explained in hypothesis 1, the use of management assumptions is considered a loophole for management to manipulate. Subramanyam and Wild (2010: 125) state that fair value is vulnerable to manipulation. This relates to the method used in measuring biological assets. The use of management assumptions causes the valuation of biological assets using fair value to have low objectivity so that they are vulnerable to manipulation and income smoothing practices. There are only 4 sample companies that use management assumptions in measuring biological assets, while the other 26 companies use active market prices that are free from management assumptions.

On the other hand, companies that use historical values are dominated by companies from Indonesia, where in the year of the study Indonesia was experiencing a weakening exchange rate. The weakening of the exchange rate that occurs causes the valuation using historical value to be more favorable because biological assets are recorded at book value rather than present value. This factor then encourages management to smooth out earnings so that reported earnings look better. This is in accordance with positive accounting theory which describes a process where by using the appropriate skills, understanding and accounting policies, managers will maximize the existence function which is directly related to the compensation and prosperity that managers will get. 
The second factor that causes this research to be insignificant is that companies that use fair value are dominated by companies that have high investor protection. The sample companies that use fair value in measuring biological assets are dominated by companies from Australia and Singapore. Based on the Strength of Investor Protection published by the World Bank in 2014, Australia ranks 66th and Singapore ranks first. Meanwhile, the sample companies that use historical values in measuring biological assets are dominated by Indonesia, which ranks 88th.

The high level of investor protection will cause accountants to be more careful in preparing financial statements. This is in accordance with the research of Leuz et al. (2003) which states that the existence of strong law enforcement for the rights of investors or noncontrolling shareholders will limit the incentives for management to take actions that only benefit management or controlling shareholders. The reduced incentives prevent management from carrying out earnings management because there are fewer things that can be hidden from investors.

\section{Simpulan}

Based on the description of the research findings and related theories above, it can be concluded that there is insufficient evidence to state that companies that use fair value in measuring biological assets have a higher tendency of income smoothing than companies that use historical values.

Based on the results of the research analysis that has been carried out in the previous chapter, the following conclusions can be drawn:

The use of fair value in the measurement of biological assets has no effect on the income smoothing practice of the company. Factors that cause the fair value measurement of biological assets to have no effect on income smoothing practices are (a) the sample companies that use fair value in measuring biological assets do not use management's assumptions in measuring their fair value, (b) sample companies have implementing GCG consistently and (c) the existence of high investor protection in the country where the sample companies are.

The use of historical values in the measurement of biological assets has an effect on the income smoothing practice of the company. This is caused by several factors, namely a) the sample companies come from countries that experience a weakening exchange rate in the study year, b) the sample companies come from countries with weak investor protection in the study year.

There is not enough evidence to state that companies that use fair value have a higher income smoothing tendency than companies that use historical values. Several factors that cause the results of this study to be insignificant include: a) sample companies that use fair value do not use much management assumptions in measuring biological assets, while companies that use historical values in measuring biological assets are dominated by companies originating from countries experiencing a weakening exchange rate. On year of research b) companies that use fair value are dominated by companies that have high investor protection. 


\section{References}

Amri, Qayuum. (2010), Kebutuhan Minyak Nabati Dunia Bergantung Pada CPO Indonesia. (Online), (http://www.kelapasawitindonesia.com), diakses pada 08 November 2015.

Ankarath, N., Mehta, K., Ghosh, T. P., \& Alkafaji, Y. (2012). Memahami IFRS standar pelaporan keuangan internasional. Jakarta: Indeks.

Argilés Bosch, J. M., García Blandón, J., \& Monllau, T. (2009). Fair value versus historic cost-valuation for biological assets: Implications for the quality of financial information. Documents de treball (Facultat d'Economia i Empresa. Espai de Recerca en Economia), 2009, E09/215.

Arikunto, Suharsimi. (2006). Prosedur Penelitian: Suatu Pendekatan Praktek. Jakarta: Rineka Cipta.

Aryanto, Y. H. (2011). Theoretical failure of IAS 41: Agriculture. The Indonesian Institute of Accountants, 1.

Bangun, D. S., \& Lestari, J. S. (2014). Analisis Perbedaan Kualitas Laba Sebelum dan Sesudah Adopsi IFRS kedalam PSAK pada Perusahaan Manufaktur yang Terdaftar di Bursa Efek Indonesia. Skripsi S1 Universitas Atma Jaya Yogyakarta yang tidak dipublikasikan.

Barlev, B \& Haddad,JR (2003). Fair Value Accounting and The Management of The Firm. Critical Persective on Accounting 14:383-415. (Online), (http://www.audytax.mx/wp-content/), diakses pada 27 Februari 2016.

Beattrice, VA (2013). Fair Valur Measurement in Agriculture and The Potential to Mislead. Economy Series Issue 5, (Online), (http://www.utgjiu.ro), diakses 8 Januari 2016.

Belkaoui, Ahmed Riahi. (2007). Teori Akuntansi: Edisi 5 - Buku 2. Jakarta: Salemba Empat Budiasih, Igan. 2007. Faktor-Faktor yang Mempengaruhi Praktik Perataan Laba. Jurnal. Jurusan Akuntansi. (Online), (http://ssrn.com), diakses 24 Mei 2016

Cahyati, Ari Dewi. (2011). Peluang Manajemen Laba Pasca Konvergensi IFRS: Sebuah Tinjauan Teoritis dan Empiris. Jurnal Riset Akuntansi dan Komputerisasi Akuntansi (Online), Vol 2 (2) 17,(http://www.ejournal-unisma.net/ojs/index.php), diakses 08 November 2015.

Danbolt, Jo dan Ress, Bill. (2007). An Experiment in Fair Value Accounting: UK Investment Vehicles. European Accounting Review, (Online), 17(2), p. 271-303 (http://papers.ssrn.com/sol3/paper.cfm), diakses 3 September 2015.

Elad, Charles. \& Kathleen Herbohn. (2011). Implementing Fair Value in the Agricultural Sector. Scotland: SATER.

Elad*, C. (2004). Fair value accounting in the agricultural sector: some implications for international accounting harmonization. European Accounting Review, 13(4), 621-641.

Fahmi, Irham. (2012). Analisis Kinerja Keuangan: Panduan bagi Akademisi, Manajer, dan Investor untuk Menilai dan Menganalisis Bisnis dari Aspek Keuangan. Bandung: Alfabeta.

FASB. (2000). FASB Concept Statement No 7: Using Cash Flow Information and Present Value in Accounting Measurements. (Online), (http://www.fasb.org), diakses 18 Desember 2015.

FASB. (2010). Statement of Financial Accounting Standards No.157: Fair Value Measurements. (Online), (http://www.fasb.org), diakses 18 Desember 2015.

Feleaga, L et all. (2012). Theorical Considerations About Implementation of IAS41 in Romania.Theorical and Applied Economics Volume XIX No. 2(567):31-38. (Online), (http://store.ectap.roo/articole/686.pdf), diakses 25 Desember 2015.

Gradiyanto, A., \& RAHARDJA, R. (2012). Pengaruh Komite Audit Terhadap Praktik Manajemen Laba (Studi Kasus Pada Perusahaan Manufaktur Di Bursa Efek Indonesia Tahun 2009-2011) (Doctoral dissertation, Fakultas Ekonomika dan Bisnis).

Harahap, Sofyan Syafri. (2011). Teori Akuntansi Edisi Revisi 2011. Jakarta. PT Rajagrafindo Persada.

Hasan, Iqbal. (2004). Analisis Data Penelitian dengan Statistik. Jakarta: Bumi Aksara.

Hery, S. E., \& Si, M. (2009). Teori Akuntansi (Edisi Pertama). Jakarta: Kencana Prenada Media Group.

Hery, S. E., \& Si, M. (2012). Analisis Laporan Keuangan. Jakarta: PT. Bumi Aksara.

IASC. (2012). IAS 4: Agriculture. (Online), (http://www.ifrs.org), diakses pada 22 Desember 2015.

Idris, I. P. (2014). Perbandingan Income Smoothing Sebelum dan Sesudah Konvergensi IFRS. Skripsi Fakultas Ekonomi dan Bisnis Universitas Hasanuddin Makassar. 
Invest

in

ASEAN.

(2012).

Agriculture

(Online) (http://investasean.asean.org/index.php/page/view/agriculture/view/850/newsid/90 4/agriculture.html), diakses tanggal 25 Juli 2016.

Kasmir. (2011). Analisis Laporan Keuangan. Jakarta: Rajawali Pers.

Kaur, J. (2013). The Fairness of the Fair Value Concept. International Journal of Businessand Commerce. Vol 3, No.3:01-10, (Online), (http://www.ijbcnet.com), diakses 22 September 2015.

Keuangan, D. S. A. (2014). Standar akuntansi keuangan per efektif 1 Januari 2015. Jakarta: Ikatan Akuntansi Indonesia.

Kusumaningtyas, Meta. (2012). Pengaruh Independensi Komite Audit dan Kepemilikan Institusional terhadap Manajemen Laba. Prestasi J uni 2012. (Online), 9(1):41-61, (www.jurnal.stiebankbpdjateng.ac.id\%2Findex.php\%2Fprestasi\%2Farticle\%2Fvie $\quad$ w\%2FMetta), diakses 1 Agustus 2016.

Lara. (2015). Australia Jadi Negara Pertanian Organik Terbesar di Dunia. (Online), (http://www.radioaustralia.net.au/indonesian/), diakses tanggal 25 Juli 2016

Lin, J. W., Li, J. F., \& Yang, J. S. (2006). The effect of audit committee performance on earnings quality. Managerial Auditing Journal. (Online), 21(9): 921-933, (https://www.researchgate.net/.../235275525), diakses 1 Agustus 2014.

Maruli, Saur \& Mita, Aria Farah. Analisis Pendekatan Nilaai Wajar dan Nilai Historis dalam Penilaian Aset Biologis pada Perusahaan Agrikultur: Tinjauan Kritis Rencana Adopsi IAS 41, Simposium Nasional Akuntnsi 13(Online), (http://pdeb.fe.ui.ac.id), diakses 19 Januari 2015.

Melurmutia. Pengaruh Komite Audit Terhadap Manajemen Laba. SKRIPSI tidak diterbitkan. (Online), (https://repository.unhas.ac.id/handle/123456789/10751), diakses 1 Agustus 2016.

Nasional, K. P. (2010). Pedoman Penulisan Karya Ilmiah: Skripsi (Doctoral dissertation, Tesis, Disertasi, Artikel, Makalah, Tugas Akhir, Laporan Penelitian (Edisi Kelima). Malang: Universitas Negeri Malang).

Pamudji, Sugeng. (2010). Pengaruh Independensi dan Efektivitas Komite Audit Terhadap Manajemen Laba. Journal Unnes (Online) 2(1):1-18, (journal.unnes.ac.idHome>Vol2, No1(2010) > Pamudji), diakses 1 Agustus 2016.

Penttinen et al. (2014). IAS Fair Value and Forest Evaluation on Farm Forestry. Proceding of the Biennial Meeting of the Scandinavian Forest Economics No. 40

Prawirosentono, Suyadi. (2002). Bahasan Komprehensif Strategi Pengambilan Keputusan Bisnis-DisertaiAnalisis dan Studi Kasus. Jakarta: Bumi Aksara.

Priyatno, Duwi. (2012). Cara Kilat Belajar Analisis Data dengan SPSS 20. Yogyakarta: CV ANDI OFFSET.

Rahmawati. (2012). Teori Akuntansi Keuangan. Yogyakarta: Graha Science.

Rayman, RA (2007). Fair Value Accounting and The Present Value Fallacy: The Need for an Alternative Conceptual Framework. The British Accounting Review 39:211-225, (Online), (http://www.scienceirect.com), diakses 24 Februari 2016.

Rohaeni, Dian \& Aryati, Titik. (2012). Pengaruh Konvergensi IFRS Terhadap Income Smoothing Dengan Kualitas Audit Sebagai Variabel Pemoderasi. Jurnal Simposium Nasional Akuntansi 15, Banjarmasin, (Online), (http://sna.akuntansi.unikal.ac.id/makalah/100-SIPE-22.pdf), diakses 08 November 2015

Ronen, J. (2008), To Fair Value or Not to Fair Value: A Broader Prespective. ABACUS Vol. 44 No. 2, (Online), (http://ssrn.com), diakses 24 Februari 2016.

Salusu. (2000). Pengambilan Keputusan Stratejik(Untuk Organisasi Publik dan Non-Profit). Jakarta: PT Grasindo.

Scott, Wiliam R. (2012). Financial Accounting Theory - Sixth Edition. Toronto: Pearson Canada.

Setiadi, Nugroho J. (2008). Business Economic and Manajerial Decision Making (Aplikasi Teori Ekonomi dan Pengambilan Keputusan Manajerial Dalam Dunia Bisnis). Jakarta: Kencana Prenada Media Group.

Sonbay, Yolinda Yanti. (2010). Perbandingan Biaya Historis dan Nilai Wajar. Kajian Akuntans Pebruari 2010, $i$ (Online), 2(1):1-8, (http://unisbank.ac.id), diakses 08 November 2015.

Stolowy, H \& Breton, G. (2000). A Framework for the Clasificationof Accountans Manipulation. HEC Accounting and Manajement Control Working Paper No. 708, (Online), (http://papers.ssrn.com), diakses 24 Februari 2016. 
Jurnal Ekonomi, Bisnis dan Pendidikan, 1(4), 2021, 380-393

Subramanyam. (2011). Analisis Laporan Keuangan Edisi 10. Jakarta: Salemba Empat.

Sudrajat, A. (2010). Konsep Dasar Pengambilan Keputusan. Akhmad Sudrajad: Tentang Pendidikan (Online).

Sugiyono. (2010). Metode Penelitian Bisnis. Bandung: Alfabeta.

Sukendar, Heri. (2010). Konsep Nilai Wajar (Faire Value) Dalam Standar Akuntansi Berbasis IFRS di Indonesia Apa dan Bagaimana. Binus Bussiness Review, (Online), 3(1):93- 106, (http://journal.binus.ac.id/index.php/BBR/article/download/1286/1151), 25 Juli 2016

Sulistiawan, Dedhy dkk. (2011). Creative Accounting: Mengungkap Manajemen Laba dan Skandal Akuntansi. Jakarta:Salemba Empat.

Sutedi, Adrian. (2011). Good Corporate Governance. Jakarta:Sinar Grafika.

Suwardjono. (2008).Teori Akuntansi: Perekayasaan Laporan Keuangan. Yogyakarta: BPFE.

Suwardjono. (2014).Teori Akuntansi: Perekayasaan Laporan Keuangan. Yogyakarta: FEB UGM.

Tudor, A. (2010). Income Smoothing and Earnings Informativeness: A matter of institutional characteristics or accounting standards?

Watts, R. L. (2003). Conservatism in accounting part I: Explanations and implications. Accounting horizons, $17(3), 207-221$.

World Bank Group. (2016). Strength of Investor Protection Index. (Online), (http://www.doingbussiness.com/rangkings), diakses pada 10 Agustus 2016. 